\title{
FAKTOR-FAKTOR YANG MEMENGARUHI PENERIMAAN DAN PENGGUNAAN SISTEM INFORMASI PENGELOLAAN KEUANGAN DAERAH (SIPKD) DALAM PERSPEKTIF THE UNIFIED THEORY OF ACCEPTANCE AND USE OF TECHNOLOGY 2 (UTAUT 2) DI KABUPATEN SEMARANG
}

\author{
Sutanto \\ Pemerintah Daerah Kabupaten Semarang \\ Imam Ghozali \\ Departemen Akuntansi, Fakultas Ekonomika dan Bisnis Universitas Diponegoro \\ Rr. Sri Handayani \\ Departemen Akuntansi, Fakultas Ekonomika dan Bisnis Universitas Diponegoro
}

\begin{abstract}
This study aims to analysis and obtain empirical evidence of factors that affected the end user's acceptance of SIPKD in Semarang Regency by using UTAUT 2 model. Sistem Informasi Pengelolaan Keuangan Daerah (SIPKD) is an integrated application as a tool of local government to improve the effectiveness of the implementation of regional financial management regulations. This application is based on efficiency, economical, effective, transparent, accountable, and auditable principles. The independent variables in this study consisted of performance expectancy, effort expectancy, social influence, facilitating conditions, hedonic motivation, and habit. The dependent variable consists of behavioral intention and use behavior. The relationship between independent variables to dependent variable was moderated by age, gender, and experience.Population variable in this research is SIPKD user or operator in 46 local area of Government of Semarang Regency that is 331 user of SIPKD. The technique of determining the sample using proportionate stratified random sampling method so that the sample in this study as many as 207 users of SIPKD. The data used were primary data collected using questionnaire survey method. The hypothesis of the research was tested by using Partial Least Squares Structural Equation Modeling (PLS-SEM) analysis with SmartPLS application v.3.2.7. The results showed that hedonic motivation and habit influence the behavioral intention to use SIPKD, the higher the level of pleasure and habits of using SIPKD then the intention to use SIPKD will be stronger. Facilitating conditions, habit and behavioral intention have an effect on Use behavior. The better the conditions that facilitate, the higher the use of SIPKD, and the intention to use the stronger the higher the SIPKD usage behavior often. The results of the test of age, gender, and experience variables showed no moderate effects on behavioral intention and use behavior.
\end{abstract}

Keywords: UTAUT 2, behavioral intention, use behavior, SIPKD 


\section{PENDAHULUAN}

Banyak manfaat yang diperoleh dalam penggunaan teknologi informasi, antara lain pekerjaan dapat dilakukan dengan lebih cepat dan dapat diakses oleh pihakpihak yang membutuhkan. Akan tetapi tidak semua organisasi berhasil dalam menerapkannya. Kemampuan perangkat keras dan perangkat lunak telah banyak mengalami kemajuan dalam membantu aktivitas yang dilakukan manusia, namun demikian masih terdapat permasalahan sistem yang belum dimanfaatkan secara optimal. Oleh sebab itu, isu yang sangat penting adalah memahami faktor-faktor penerimaan sistem informasi oleh individu dalam suatu organisasi.

Sistem teknologi informasi diadopsi berdasarkan keputusan manajer, namun berhasil atau tidaknya penggunaan teknologi informasi sangat dipengaruhi oleh penerimaan dan penggunaan individu yang memakainya. Banyak sistem mengalami kegagalan karena aspek teknisnya, seperti buruknya kualitas teknis sistem informasi yang banyak mengandung kesalahan sintak, kesalahan logik dan bahkan kesalahan informasi (Hartono, 2008). Saat ini banyak organisasi yang menerapkan sistem teknologi informasi modern dan canggih dengan biaya tinggi, akan tetapi permasalahan yang timbul adalah masih rendahnya penggunaan sistem informasi secara berkesinambungan. Rendahnya penggunaan sistem informasi diidentifikasi menjadi penyebab utama productivity paradox yaitu mahalnya investasi di bidang sistem tetapi return yang dihasilkan rendah (Venkatesh dan Davis, 2000). Penelitian menunjukkan bahwa penyebab gagalnya penggunaan sistem informasi saat ini dikarenakan lebih pada aspek keperilakuan (behavioral) yang berarti bahwa perilaku penolakan terhadap sistem teknologi informasi dari pemakainya (Hartono, 2008).

Penelitian tentang SIPKD yang berkaitan dengan penerimaan dan penggunaan teknologi informasi telah beberapa kali dilakukan, akan tetapi hasilnya tidak konklusif. Venkatesh dkk. (2003) menunjukkan bahwa ekspektasi kinerja, ekspektasi usaha dan pengaruh sosial memiliki pengaruh yang signifikan terhadap niat. Kondisi yang memfasilitasi dan niat memiliki pengaruh signifikan terhadap perilaku penggunaan teknologi. Al-Gahtani dkk. (2007) juga mengungkapkan bahwa performance expectancy berpengaruh positif terhadap niat untuk menggunakan komputer, tetapi jenis kelamin dan usia tidak dapat memoderasi pengaruh hubungan performance expectancy dengan behavioral 
intention. Selain itu, Effort expectancy juga tidak berpengaruh signifikan terhadap niat menggunakan komputer dengan variabel moderasi usia dan jenis kelamin. Norma Subyektif berpengaruh positif terhadap behavioral intention, tetapi berinteraksi negatif seiring dengan meningkatnya tingkat usia dan pengalaman dalam menggunakan komputer. Facilitating conditions berpengaruh negatif lemah terhadap use behavior dengan bertambahnya usia, namun berpengaruh positif kuat dengan meningkatnya experience.

Lawan dan Dahalin (2011) membuktikan bahwa performance expectancy, management effectiveness, social influence, dan program effectiveness berpengaruh signifikan terhadap niat perilaku penerimaan pengguna Telecentre, tetapi tidak dipengaruhi secara signifikan oleh effort expectancy. Facilitating conditions dan behavioral intention berpengaruh positif terhadap penerimaan pengguna (user aceptance) Telecentre. Pahnila dkk. (2011) juga menunjukkan dalam penelitiannya bahwa habit, facilitating conditions dan niat berpengaruh signifikan terhadap penggunaan aktual dari Tao Bao, social influence berpengaruh signifikan terhadap behavioral intention, kecemasan (anxiety) berpengaruh positif signifikan terhadap penggunaan aktual (actual use) sistem, performance expectancy merupakan salah satu faktor yang paling signifikan yang berpengaruh terhadap niat dan effort expectancy merupakan faktor penting dalam penerimaan sistem informasi.

Venkatesh dkk. (2012) menyatakan bahwa hedonic motivation berpengaruh terhadap behavioral intention yang dimoderasi oleh variabel age, gender, dan experience. Pengaruh price value terhadap behavioral intention tersebut dimoderasi oleh age dan gender. Habit bepengaruh langsung dan dimediasi oleh penggunaan teknologi yang dimoderasi oleh perbedaan age, gender, dan experience masing-masing individu. Harsono dan Suryana (2014) menunjukkan hampir semua variabel independen, yaitu performance expectancy, effort expectancy, social influence, facilitating conditions, hedonic motivation, dan habit kecuali price value mempengaruhi niat perilaku dan perilaku menggunakan Line.

Iriani dkk. (2014) juga menyimpulkan bahwa variabel performance expectancy, effort expectancy, social influence dinyatakan diterima tetapi facilitating conditions berpengaruh lemah terhadap penerimaan SIPKD. Widnyana dan Yadnyana (2015) menunjukkan bahwa niat 
menggunakan SIPKD dipengaruhi positif dan signifikan oleh variabel ekspektasi kinerja dan pengaruh social, tetapi tidak dipengaruhi oleh variabel ekspektasi usaha. Selain itu, perilaku menggunakan sistem dipengaruhi positif dan signifikan oleh variabel kondisi yang memfasilitasi dan niat menggunakan.

Penelitian ini dilakukan di Pemerintah Kabupaten Semarang karena Pemerintah Kabupaten Semarang sejak tahun 2010 telah mengaplikasikan SIPKD untuk mendukung kinerja organisasi. Namun kenyataannya, implementasi SIPKD di Kabupaten Semarang masih menemui kendala-kendala, yaitu: (1) aplikasi SIPKD belum sempurna atau sistem yang digunakan belum selaras dengan konsep, (2) sarana dan prasarana belum memadai, seperti masih kurangnya ketersediaan komputer yang benar-benar mendukung kompleksitas sistem dan jaringan intranet yang dipakai masih lemah sehingga belum optimal dalam mendukung SIPKD, (3) pemahaman user terhadap mekanisme pengoperasian aplikasi SIPKD belum dikuasai sepenuhnya sehingga terdapat ketidaksesuaian dalam memjalankan aplikasi yang pada akhirnya akan menyebabkan kegagalan dalam penyelesaian operasional aplikasi SIPKD.

\section{TINJAUAN PUSTAKA DAN PENGEMBANGAN HIPOTESIS Unified Theory of Acceptance and Use of Technology (UTAUT)}

\section{Unified Theory of Acceptance and} Use of Technology (UTAUT) adalah kerangka yang dirancang oleh Venkatesh dkk. (2003) untuk memprediksi penerimaan teknologi dalam pengaturan organisasi. Tujuan utama UTAUT yaitu untuk membantu organisasi dalam memahami reaksi pengguna terhadap pengenalan teknologi baru (Wang dan Yang, 2005). Model UTAUT memiliki 4 faktor utama yang berpengaruh terhadap behavioral intention dan use behavior teknologi informasi, yaitu performance expectancy, effort expectancy, social influence, dan facilitating conditions. Model tersebut juga menggunakan 4 variabel moderator yaitu gender, voluntary of use, age, dan experience.

\section{Unified Theory of Acceptance and Use of Technology 2 (UTAUT 2)}

Unified Theory of Acceptance and Use of Technology 2 (UTAUT 2) merupakan pengembangan dari model UTAUT yang dilakukan oleh Venkatesh dkk. (2012). Tujuan adanya UTAUT 2 yakni untuk mempelajari penerimaan dan penggunaan teknologi dalam konteks konsumen. Dalam 
UTAUT 2 terdapat penambahan 3 variabel baru dan menghilangkan 1 variabel moderator yaitu voluntariness of use yang berasal dari model UTAUT. Konstruk yang ada dalam UTAUT 2 adalah performance expectancy, effort expectancy, social influence, facilitating conditions, hedonic motivation, price value dan habit. Dalam UTAUT 2 hanya terdapat 3 variabel moderator yaitu age, gender, dan experience. Ketiga variabel tersebut memoderasi efek konstruk behavioral intention dan use behavior.

\section{Sistem Informasi Pengelolaan Keuangan Daerah (SIPKD)}

SIPKD merupakan subsistem dari Sistem Informasi Keuangan Daerah (SIKD). Menteri Keuangan melaksanakan SIKD secara nasional, sedangkan di daerah dilaksanakan oleh masing-masing pemerintah daerah. SIKD yang diselenggarakan oleh pemerintah daerah mencakup: (1) penyampaian informasi anggaran, pelaksanaan anggaran, dan pelaporan keuangan daerah, (2) penyajian Informasi Keuangan Daerah (IKD) dalam situs resmi Pemerintah Daerah, dan (3) penyediaan IKD untuk mendukung SIKD secara nasional. Dalam rangka menunjang penyusunan anggaran, pelaksanaan anggaran, dan pelaporan keuangan daerah maka pemerintah daerah menyelenggarakan SIPKD.

Dalam Peraturan Pemerintah Nomor 56 Tahun 2005 dijelaskan bahwa SIPKD merupakan serangkaian proses dan prosedur yang dilaksanakan oleh pemerintah daerah untuk penyusunan anggaran, pelaksanaan anggaran dan pelaporan keuangan daerah. Direktorat Jenderal Keuangan Daerah Kementerian Dalam Negeri (2016) mendefinisikan SIPKD secara lebih luas sebagai aplikasi terpadu yang digunakan sebagai alat bantu pemerintah daerah untuk meningkatkan efektifitas penerapan peraturan di bidang pengelolaan keuangan daerah yang berasaskan efisiensi, ekonomis, efektif, transparan, akuntabel dan auditabel.

\section{Model Penelitian Yang Dihipotesiskan}

Penelitian ini mengacu pada model penelitian penerimaan dan penggunaan teknologi informasi Unified Theory of Acceptance and Use of Technologi 2 (UTAUT 2) oleh Venkatesh dkk. (2012). Terdapat perbedaan antara penelitian Venkatesh dkk. (2012) dengan penelitian yang akan penulis lakukan, yaitu Venkatesh dkk. (2012) melakukan penelitian pada organisasi swasta dan dalam sudut pandang konsumen, sedangkan penelitian ini 
dilakukan pada organisasi sektor publik yang mempunyai karakter berbeda. Konstruk price value dari UTAUT 2 dihilangkan karena SIPKD merupakan fasilitas teknologi informasi yang tersedia tanpa mengeluarkan biaya bagi pengguna.

\section{GAMBAR 1}

MODEL PENELITIAN YANG DIHIPOTESISKAN

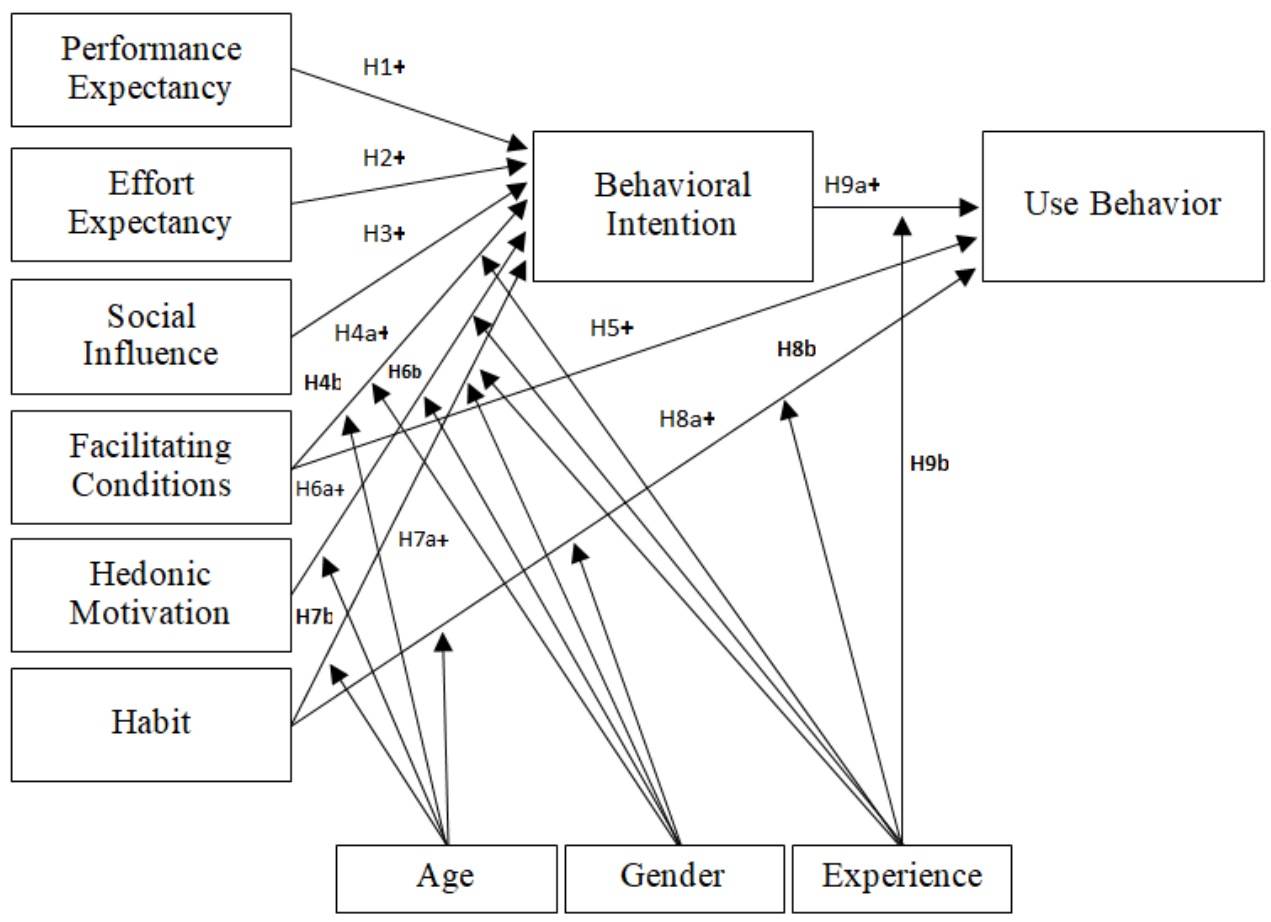

Sumber: Venkatesh dkk. (2012) yang dimodifikasi

\section{Hipotesis Penelitian}

Pengaruh faktor ekspektasi kinerja (performance expectancy) terhadap niat perilaku (behavioral intention) untuk menggunakan SIPKD

Performance expectancy

didefinisikan tingkat kepercayaan pengguna bahwa dalam menggunakan sistem informasi akan dapat meningkatkan kinerja pekerjaannya (Taylor dan Todd, 1995).
Ekspektasi kinerja merupakan prediktor terkuat dari niat untuk menggunakan sistem informasi dan signifikan pada semua pengukuran dalam penggunaan sukarela maupun wajib. Hal ini sesuai dengan penelitian Venkatesh dan Davis (2000), Lawan dan Dahalin (2011), Venkatesh dkk. (2012), Mahendra dan Affandy (2013), Iriani dkk. (2014), serta Widnyana dan Yadnyana 
(2015) yang menunjukkan bahwa performance expectancy merupakan salah satu faktor penentu yang paling penting dari penerimaan sistem teknologi informasi. Ekspektasi kinerja dalam konteks penelitian ini menyiratkan bahwa pengguna akan berekspektasi bahwa SIPKD berguna karena memungkinkan mereka untuk melakukan proses penyusunan anggaran, pelaksanaan anggaran maupun pelaporan keuangan daerah secara efektif. Berdasarkan penjelasan tersebut, maka hipotesis yang akan diuji adalah:

$\mathrm{H}_{1}$ : Ekspektasi kinerja (performance expectancy) berpengaruh positif terhadap niat perilaku (behavioral intention) untuk menggunakan SIPKD.

\section{Pengaruh faktor ekspektasi usaha (effort expectancy) terhadap niat perilaku (behavioral intention) untuk menggunakan SIPKD}

Effort expectancy adalah tingkat kemudahan pengguna dalam penggunaan sistem informasi (Taylor dan Todd, 1995). Davis dkk. (1989) mengidentifikasi bahwa penggunaan teknologi informasi dipengaruhi oleh kemudahan penggunaan. Tingkat kemudahan penggunaan terhadap suatu teknologi informasi akan menimbulkan perasaan dalam diri individu bahwa sistem itu mempunyai manfaat sehingga akan menimbulkan rasa nyaman penggunaannya (Venkatesh dan Davis, 2000).

Penelitian yang dilakukan dengan menggunakan model UTAUT, effort expectancy berpengaruh positif terhadap behavioral intention dalam penggunaan sistem informasi (Venkatesh dkk., 2003; Mahendra dan Affandy, 2013; Iriani dkk., 2014). Namun, effort expectancy dalam beberapa penelitian ditemukan tidak berpengaruh signifikan terhadap behavioral intention (Lawan dan Dahalin, 2011; Widnyana dan Yadnyana, 2015). Berdasarkan uraian di atas hipotesis yang diuji adalah:

$\mathrm{H}_{2}$ : Ekspektasi usaha (effort expectancy) berpengaruh positif terhadap niat perilaku (behavioral intention) untuk menggunakan SIPKD.

\section{Pengaruh faktor pengaruh sosial (social influence) terhadap niat perilaku (behavioral intention) untuk menggunakan SIPKD}

Social influence didefinisikan sejauh mana individu merasakan bahwa orangorang yang dianggapnya penting percaya untuk menggunakan sistem yang baru (Venkatesh dkk., 2003). Ketika dihadapkan pada sesuatu yang baru individu cenderung membutuhkan dukungan dari orang lain. Pengaruh sosial ditemukan sebagai faktor 
signifikan dalam mempengaruhi niat perilaku individual untuk menggunakan sistem informasi baru (Taylor dan Todd, 1995).

Hasil penelitian TRA, TAM, MM, TPB, TAM/TPB, MPCU, IDT, dan SCT menunjukkan bahwa konstruk social influence tidak berpengaruh signifikan terhadap penggunaan teknologi secara sukarela. Namun, konstruk social influence berpengaruh signifikan ketika penggunaan teknologi diwajibkan (mandatory). Venkatesh dan Davis (2000) menemukan bahwa pengaruh sosial terhadap penggunaan teknologi secara wajib menjadi penting hanya pada tahap awal dari penggunaan dan akhirnya menjadi tidak signifikan di pemakaian yang sudah jelas. Hasil empiris penelitian yang dilakukan oleh Sedana dan Wijaya (2010), Lawan dan Dahalin (2011), Mahendra dan Affandy (2013), serta Iriani dkk. (2014) membuktikan bahwa faktor sosial berpengaruh positif terhadap minat penggunaan sistem teknologi informasi. Berdasarkan uraian di atas hipotesis yang diuji adalah:

$\mathrm{H}_{3}$ : Pengaruh sosial (social influence) berpengaruh positif terhadap niat perilaku (behavioral intention) untuk menggunakan SIPKD.
Pengaruh faktor kondisi yang memfasilitasi (facilitating conditions) terhadap niat perilaku (behavioral intention) untuk menggunakan SIPKD

Facilitating conditions didefinisikan sejauh mana seorang individu percaya bahwa infrastruktur organisasi dan teknis yang ada mendukung penggunaan sistem (Venkatesh dkk., 2003). Secara umum konsumen dengan tingkat kondisi yang memfasilitasi lebih rendah akan memiliki niat yang lebih rendah untuk menggunakan internet mobile (Venkatesh dkk., 2012). Lawan dan Dahalin (2011) dan Mahendra dan Affandy (2013) membuktikan bahwa kondisi yang memfasilitasi mempengaruhi niat perilaku (behavioral intention) SIPKD.

Dampak kondisi yang memfasilitasi tersebut dimoderasi oleh usia, jenis kelamin, dan pengalaman. Konsumen yang memiliki usia lebih tua cenderung menghadapi lebih banyak kesulitan dalam memproses informasi baru (Morris dkk., 2005). Kesulitan ini dapat dikaitkan dengan penurunan kognitif dan memori kemampuan yang berhubungan dengan proses penuaan. Oleh karena itu, konsumen yang usianya lebih tua cenderung lebih mementingkan ketersediaan dukungan yang memadai dibandingkan dengan konsumen yang usianya lebih muda (Hall dan Mansfield, 1975). 
Perbedaan gender dalam orientasi tugas dan penekanan terhadap perantaranya menjadi lebih jelas dengan bertambahnya usia (Morris dkk., 2005). Jika seseorang semakin bertambah usianya terutama dari remaja ke dewasa, maka diferensiasi peran gender mereka akan lebih signifikan. Dengan demikian, wanita yang lebih tua akan lebih bergantung pada kondisi memfasilitasi. Bukti empiris perbedaan gender dalam hubungannya dengan kondisi memfasilitasi menjadi lebih jelas dengan bertambahnya usia (Venkatesh dkk., 2003; Morris dkk., 2005). Selain itu, laki-laki bersedia untuk menghabiskan lebih banyak usaha untuk mengatasi kendala dan kesulitan untuk mencapai tujuan mereka, atau dalam menggunakan teknologi baru laki-laki lebih mempertimbangkan manfaat dibandingkan wanita. Wanita akan lebih mempertimbangkan kemudahan penggunaan dalam menentukan keputusan untuk menggunakan suatu teknologi baru (Venkatesh dan Morris, 2000). Dengan demikian, laki-laki cenderung kurang mengandalkan kondisi yang memfasilitasi saat mempertimbangkan penggunaan teknologi baru, sedangkan wanita cenderung lebih menekankan pada faktor-faktor pendukung eksternal.
Selain usia dan gender, pengalaman juga dapat memoderasi hubungan antara facilitating conditions dan niat perilaku. Pengalaman yang lebih banyak dapat menyebabkan familiaritas yang lebih besar terhadap teknologi dan struktur pengetahuan yang lebih baik, sehingga akan dapat mengurangi ketergantungan pengguna terhadap dukungan eksternal (Alba dan Hutchinson, 1987). Berdasarkan uraian dan bukti empiris di atas maka hipotesis yang diuji adalah:

$\begin{array}{rlrr}\mathrm{H}_{4 a} & \text { Kondisi yang } & \text { memfasilitasi } \\ & \text { (facilitating conditions) } & \text { berpengaruh } \\ \text { positif terhadap niat } & \text { perilaku } \\ & \text { (behavioral intention) } & \text { untuk }\end{array}$
menggunakan SIPKD.

$\mathrm{H}_{4 \mathrm{~b}}$ : Usia (age), jenis kelamin (gender), dan pengalaman (experience) akan memoderasi pengaruh kondisi yang memfasilitasi (facilitating conditions) terhadap niat perilaku (behavioral intention) untuk menggunakan SIPKD, sehingga pengaruhnya akan lebih kuat pada wanita yang lebih tua, dengan pengalaman yang kurang. 


\section{Pengaruh faktor kondisi yang memfasilitasi (facilitating conditions) terhadap perilaku menggunakan (use behavior) SIPKD}

Facilitating conditions dalam UTAUT mempengaruhi penggunaan teknologi secara langsung. Pengaruh tersebut didasarkan pada facilitating conditions yang berfungsi sebagai pengendali perilaku aktual dan pengaruh perilaku langsung (Ajzen, 1991). Venkatesh dkk. (2003) menunjukkan bahwa facilitating conditions tidak berpengaruh signifikan terhadap behavioral intention, tetapi berpengaruh positif terhadap use behavior dengan efek yang lebih kuat untuk pekerja yang usianya lebih tua dengan pengalaman yang semakin meningkat. Venkatesh dkk. (2012) dalam penelitiannya juga menyatakan bahwa facilitating conditions memiliki dampak signifikan terhadap use behavior. Lawan dan Dahalin (2011) mengemukakan hal yang sama bahwa faktor facilitating conditions berpengaruh terhadap use behavior pada penerimaan telecenter di Nigeria. Hasil penelitian tersebut sesuai dengan Widnyana dan Yadnyana (2015) yang menemukan bahwa facilitating conditions berpengaruh positif signifikan terhadap perilaku menggunakan SIPKD. Berdasarkan uraian tersebut maka hipotesis penelitian yang diajukan adalah:
$\mathrm{H}_{5}$ : Kondisi yang memfasilitasi (facilitating conditions) berpengaruh positif terhadap perilaku menggunakan (use behavior) SIPKD.

\section{Pengaruh faktor motivasi hedonis (hedonic motivation) terhadap niat perilaku (behavioral intention) untuk menggunakan SIPKD}

Hedonic motivation didefinisikan kesenangan yang diperoleh dari penggunaan teknologi, hal ini telah terbukti berperan penting dalam penerimaan dan penggunaan teknologi (Brown dan Venkatesh, 2005). Dalam penelitian sistem informasi, hedonic motivation berpengaruh langsung terhadap penerimaan dan penggunaan teknologi (Heijden, 2004; Thong dkk., 2006). Putra dan Ariyanti (2013) dan Raman dan Don (2013) juga membuktikan bahwa hedonic motivation berpengaruh positif signifikan terhadap behavioral intention.

Pengaruh hedonic motivation terhadap niat perilaku dimoderasi oleh usia, jenis kelamin, dan pengalaman. Moderasi tersebut disebabkan adanya perbedaan daya inovasi konsumen, pencarian hal-hal baru, dan persepsi hal baru terhadap penggunaan teknologi. Hedonic motivation akan kurang berperan dalam penggunaan teknologi dengan meningkatnya pengalaman. Semakin pengalaman meningkat maka semakin 
berkurang daya tarik hal baru tentang pemberian kontribusi hedonic motivation dalam penggunaan teknologi sehingga konsumen menggunakan teknologi untuk tujuan yang lebih pragmatis yaitu efisiensi atau efektivitas. Moderasi usia dan jenis kelamin pada motivasi hedonis, pada tahap awal penggunaan teknologi baru, seorang laki-laki yang berusia muda menunjukkan kecenderungan yang lebih besar untuk mencari hal baru (Chau dan Hui, 1998).

Harsono dan Suryana (2014) menemukan variabel age tidak memoderasi hubungan antara hedonic motivation dan behavioral intention, tetapi variabel gender dan experience memoderasi hubungan hedonic motivation terhadap behavioral intention secara parsial. Berdasarkan literatur dan bukti empiris tersebut maka hipotesis penelitian yang diajukan adalah:

$\mathrm{H}_{6 \mathrm{a}}$ : Motivasi hedonis (hedonic motivation) berpengaruh positif terhadap niat perilaku (behavioral intention) untuk menggunakan SIPKD.

$\mathrm{H}_{6 \mathrm{~b}}$ : Usia(age), jenis kelamin(gender), dan pengalaman (experience) akan memoderasi pengaruh motivasi hedonis(hedonic motivation)terhadap niat perilaku (behavioral intention)untuk menggunakan SIPKD, sehingga pengaruhnya akan lebih kuat pada laki-laki muda di tahap awal pengalaman dengan SIPKD.

\section{Pengaruh faktor kebiasaan (habit) terhadap niat perilaku (behavioral intention) untuk menggunakan SIPKD}

Habit didefinisikan sejauh mana orang cenderung secara otomatis melakukan perilaku karena belajar (Limayem dkk., 2007). Ajzen dan Madden (2005) menyatakan bahwa kebiasaan adalah membangun persepsi yang mencerminkan hasil pengalaman sebelumnya. Hal ini diperjelas oleh pendapat Kim dan Malhotra (2005) yang menyatakan bahwa penggunaan sebelumnya merupakan prediktor yang kuat dalam penggunaan teknologi di masa mendatang. Pahnila dkk. (2011), Harsono dan Suryana (2014) dan Prabowo (2015) menemukan bahwa faktor kebiasaan memiliki pengaruh yang signifikan terhadap niat perilaku.

Age dan gender mencerminkan perbedaan dalam pengolahan informasi yang dapat mempengaruhi ketergantungan pada kebiasaan untuk berperilaku. Seseorang yang berusia lebih tua cenderung mengandalkan pengolahan informasi otomatis (Jennings dan Jacoby, 1993). Selain itu, perbedaan gender akan lebih memoderasi efek kebiasaan. Penelitian telah menunjukkan bahwa wanita cenderung lebih 
memperhatikan hal yang detail daripada pria. Venkatesh dkk. (2012) mengemukakan bahwa kebiasaan memiliki efek yang kuat pada pria yang usianya lebih tua. Hal ini disebabkan pria yang usianya lebih tua memiliki lebih banyak pengalaman yang cenderung mengandalkan kebiasaan mereka.

Berdasarkan literatur dan bukti empiris tersebut maka hipotesis penelitian yang diajukan adalah:

$\mathrm{H}_{7 \mathrm{a}}$ : Kebiasaan (habit) berpengaruh positif terhadap niat perilaku (behavioral intention) untukmenggunakan SIPKD.

$\mathrm{H}_{7 \mathrm{~b}}$ : Usia(age), jenis kelamin(gender), dan pengalaman (experience) akan memoderasi pengaruh kebiasaan(habit) terhadap niat perilaku(behavioral intention)untuk menggunakan SIPKD, sehingga pengaruhnya akan lebih kuat pada laki-laki yang lebih tua dengan tingkat pengalaman yang tinggi dengan SIPKD.

\section{Pengaruh faktor kebiasaan (habit) terhadap perilaku menggunakan (use behavior) SIPKD}

Habit memiliki pengaruh terhadap penggunaan teknologi sebagaimana ditunjukkan Venkatesh dkk. (2012) yang menyatakan bahwa habit berpengaruh terhadap penggunaan teknologi secara langsung dan juga dimediasi oleh behavioral intention. Harsono dan Suryana (2014) menyebutkan bahwa kebiasaan berpengaruh positif terhadap perilaku dalam penggunaan aplikasi Line. Relevan dengan hasil penelitian di atas, Venkatesh dkk. (2012) juga menyatakan bahwa usia, jenis kelamin, dan pengalaman akan dapat memoderasi efek kebiasaan terhadap penggunaan teknologi. Oleh karena itu, pria yang usianya lebih tua dengan tingkat pengalaman yang tinggi akan memiliki pengaruh lebih kuat terhadap penggunaan teknologi. Berdasarkan uraian tersebut maka hipotesis penelitian yang diuji adalah:

$\mathrm{H}_{8} \mathrm{a}$ : Kebiasaan (habit) berpengaruh positif terhadap perilaku menggunakan (use behavior) SIPKD.

$\mathrm{H}_{8}$ b: Usia (age), jenis kelamin(gender), dan pengalaman (experience) akan memoderasi pengaruh kebiasaan(habit) terhadap perilakumenggunakan (use behavior) SIPKD, sehingga pengaruhnya akan lebih kuat pada pria yang lebih tua dengan tingkat pengalaman yang tinggi dengan SIPKD.

\section{Pengaruh niat perilaku (behavioral intention) terhadap perilaku menggunakan (use behavior) SIPKD}

\section{Theory of Reasoned Action (TRA)}

menyatakan bahwa niat individu untuk tidak melakukan atau melakukan suatu perilaku 
merupakan penentu langsung dari tindakan atau perilaku. Individu akan melakukan suatu perilaku (behavior) bila memiliki keinginan atau niat (behavioral intention) untuk melakukannya. Davis dkk. (1989), Taylor dan Todd (1995), serta Venkatesh dan Davis (2000) dalam penelitiannya menunjukkan bahwa niat perilaku merupakan prediksi yang baik atas penggunaan teknologi oleh pegguna sistem. Hasil ini didukung oleh penelitian Venkatesh dkk. (2003), Al-Gahtani dkk. (2007), Lawan dan Dahalin (2011), serta Widnyana dan Yadnyana (2015) yang juga menemukan bahwa niat pemanfaatan berpengaruh positif signifikan terhadap perilaku penggunaan sistem.

Pengaruh behavioral intention terhadap use behavior juga dipengaruhi oleh pengalaman (experience). Dengan meningkatnya pengalaman, konsumen atau user memiliki lebih banyak kesempatan untuk memperkuat kebiasaan mereka karena memiliki lebih banyak waktu untuk melakukan perilaku yang terkait (Kim dan Malhotra, 2005). Akibatnya, efek dari niat perilaku pada penggunaan teknologi akan berkurang seiring dengan meningkatnya pengalaman. Kim dkk. (2005) menunjukkan bahwa niat penggunaan berinteraksi secara signifikan dengan penggunaan masa lalu untuk mempengaruhi penggunaan selanjutnya. Jasperson dkk. (2005) menyatakan bahwa dengan meningkatnya pengalaman, perilaku rutin menjadi otomatis dan dipengaruhi faktor terkait lainnya, akibatnya, efek niat perilaku pada penggunaan teknologi akan berkurang dengan pengalaman yang semakin meningkat.

Dengan demikian hipotesis penelitian akan menguji kembali pengaruh niat terhadap perilaku menggunakan SIPKD sebagai berikut:

$\mathrm{H}_{9 \mathrm{a}}$ : Niat perilaku (behavioral intention) berpengaruh positif terhadap perilaku menggunakan (use behavior) SIPKD.

$\mathrm{H}_{9 \mathrm{~b}}$ : Pengalaman(experience)akan memoderasi pengaruhniat perilaku (behavioral intention) terhadap perilaku menggunakan (use behavior) SIPKD, sehingga pengaruhnya akan lebih kuat bagi pengguna dengan pengalaman yang kurang.

\section{METODE PENELITIAN}

\section{Metode Pengumpulan Data}

Penelitian ini dilakukan pada perangkat daerah Pemerintah Kabupaten Semarang. Populasi dalam penelitian ini adalah pengguna atau operator SIPKD di tingkat perangkat daerah sejumlah 331 
pengguna SIPKD. Sampel yang digunakan dalam penelitian ini yaitu 230 pengguna SIPKD yang tersebar di 46 perangkat daerah Pemerintah Kabupaten Semarang. Data primer dikumpulkan melalui kuesioner dengan menggunakan skala likert 5 alternatif pilihan yakni 1 (sangat tidak setuju), 2 (tidak setuju), 3 (netral), 4 (setuju), dan 5 (sangat setuju.

\section{Metode Analisis}

Pengolahan data penelitian menggunakan pendekatan Partial Least Squares-Structural Equation Modeling (PLS-SEM) dengan aplikasi software SmartPLS 3.2.7. Pengujian hipotesis dilakukan melalui 2 model substruktur yaitu model pengukuran (outer model) dan model struktural (inner model). Outer model berfungsi untuk menilai validitas dan reliabilitas instrumen penelitian yang meliputi validitas konvergen dan validitas determinan dengan melihat nilai loading faktor, nilai $A V E$, perbandingan akar kuadrat $A V E$, dan composite reliability. Inner model menunjukkan hubungan atau kekuatan estimasi antar variabel laten atau konstruk (Ghozali dan Latan, 2016) dengan menggunakan nilai adjusted $R^{2}$ untuk setiap variabel laten endogen sebagai kekuatan prediksi dari model struktural, Stone-Geiser
Test untuk menguji predictive relevance, dan Goodness of Fit (GoF) untuk mengukur fit model secara keseluruhan yang selanjutnya akan dihitung partial F-test atau effect size untuk mengetahui besarnya proporsi varian variabel eksogen terhadap variabel endogen.

Langkah selanjutnya yakni dengan menggunakan $Q^{2}$ predictive relevance melalui prosedur blindfolding. Jika nilai $Q^{2}>$ 0 menunjukkan model mempunyai predictive relevance sedangkan jika nilai $Q^{2}<0$ menunjukkan model kurang memiliki predictive relevance. Nilai $Q^{2}$ model sebesar 0,02 (predictive relevance lemah), $Q^{2}$ model sebesar 0,15 (moderate) dan $Q^{2}$ model sebesar 0,35 (kuat).

Uji hipotesis dilakukan dengan melihat nilai signifikansi p-value dengan tingkat signifikansi $5 \%$ (one-tailed). Signifikansi hubungan antar variabel laten eksogen dan endogen dilihat dari besarnya nilai $t$-statistik atau t-hitung dan $p$-value. Jika nilai t-statistik > 1,96 dan p-value < 0,05 dapat diartikan signifika (Hipotesis diterima) dan jika Nilai t-statistik $<1,96$ dan p-value> 0,05 dikatakan tidak signifikan (hipotesis tidk diterima). 
HASIL PENELITIAN DAN

\section{PEMBAHASAN}

\section{Model Pengukuran (Outer Model)}

Pengujian model pengukuran digunakan untuk memvalidasi model penelitian yang dibangun. Dua parameter utama tersebut yakni pengujian validitas konstruk (validitas konvergen dan

determinan) dan pengujian konsistensi internal (reliabilitas) konstruk. Pengujian validitas konstruk dan konsistensi internal telah terpenuhi namun dari 28 indikator yang ada, terdapat 5 indikator yang tidak valid $(<$ $0,5)$ sehingga indikator tersebut harus dihapus untuk selanjutnya akan dilakukan pengujian hipotesis.

Gambar 2.

Hasil Uji Statistik atas Model Struktural

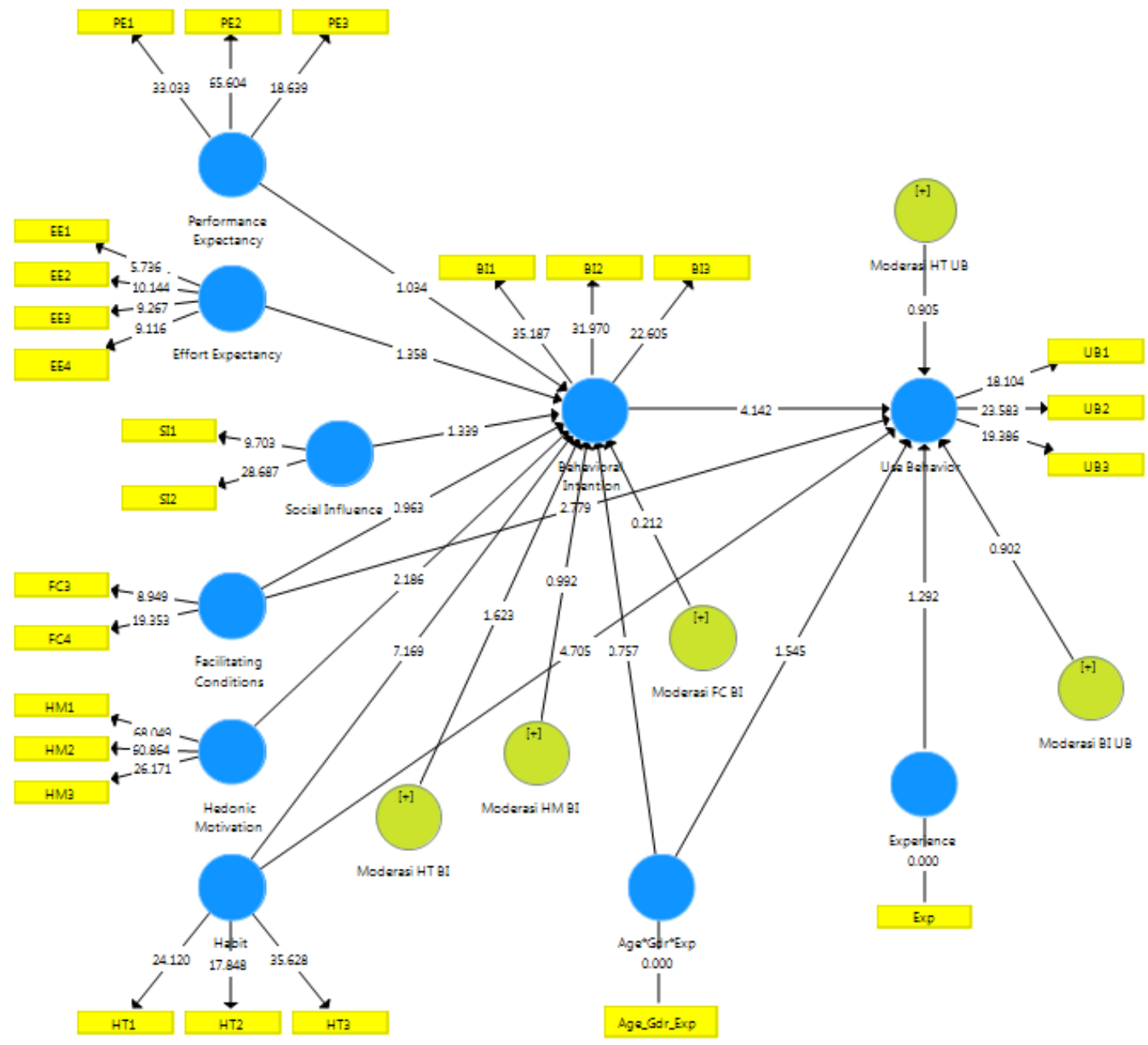

Sumber: Output SmartPLS v.3.2.7, 2017 


\section{Model Struktural (Inner Model)}

\section{Adjusted R $\mathbf{R}^{2}$}

Hasil uji diperoleh nilai Adjusted $R^{2}$ variabel behavioral intention sebesar 0,414 dan use behaviorsebesar 0,457. Nilai Adjusted $R^{2} \quad$ sebesar 0,414 variabel behavioral intention artinya bahwa kontribusi yang diberikan variabel performance expectancy, effort expectancy, social influence, facilitating conditions, hedonic motivation, dan habit terhadap behavioral intention dengan dimoderasi variabel age, gender, dan experience sebesar $41,4 \%$ (moderat), sisanya $(58,6 \%)$ dijelaskan oleh variabel lain di luar penelitian. Nilai Adjusted R-Square sebesar 0,457 Variabel use behavior yang berarti bahwa kontribusi yang diberikan variabel performance expectancy, effort expectancy, social influence, facilitating condition, hedonic motivation, habit dan behavioral intention terhadap use behavior dengan dimoderasi variabel age, gender, dan experience sebesar $45,70 \%$ (moderat), sedangkan sisanya $(54,30 \%)$ dijelaskan oleh variabel lain di luar penelitian.

\section{Effect Size (f Square/ $\mathbf{f}^{\mathbf{2}}$ )}

Effect size dalam model penelitian ini menunjukkan bahwa di antara seluruh variabel yang berpengaruh terhadap behavioral intention, hanya variabel habit memberikan pengaruh 0,298 (kategori besar) sedangkan variabel lain yakni effort expectatancy $(0,008)$, facilitating conditions (0,005), hedonic motivation (0,026), performance expectatancy $(0,006)$ dan social influence $(0,012)$ memberikan pengaruh dengan kategori menengah dan kecil. Efect size yang diberikan oleh variabel habit terhadap use behavior sebesar 0,146 (kategori menengah) sedangkan variabel lain yang terdiri dari behavioral intention $(0,110)$ dan facilitating conditions $(0,047)$ dengan kategori menengah.

\section{$\mathbf{Q}^{2}$ Predictive Relevance}

Nilai $Q^{2}$ variabel behavioral intention sebesar 0,271 dan use behavior sebesar 0,263. Nilai $Q^{2}$ lebih besar dari nol $\left(Q^{2}>0\right)$ yang berarti bahwa model mempunyai relevansi prediktif. Nilai $Q^{2}$ model sebesar 0,271 dan $0,263>0,15$ menunjukkan bahwa model memiliki predictive relevance yang moderate. Hal ini didukung dengan nilai goodness of fit yang dihasilkan melalui standardized root mean residual (SRMR) sebesar $0,072<0,080$ yang berarti model penelitian ini fit dengan data empiris. 
Pembahasan

Pengaruh faktor ekspektasi kinerja (performance expectancy) terhadap niat perilaku (behavioral intention)untuk menggunakan SIPKD

Pengujian statistik menghasilkan nilai koefisien jalur ekspektasi kinerja sebesar 0,071, nilai t statistik 1,034, dan $p$ value 0,301. Hasil ini menunjukkan bahwa ekspektasi kinerja tidak berpengaruh terhadap niat perilaku untuk menggunakan SIPKD (H1 Ditolak). Pengaruh yang tidak signifikan tersebut diindikasikan penyebabnya yaitu (1) kurangnya penghargaan yang diberikan kepada pengelola keuangan yang tidak sebanding dengan tugas dan peran yang harus diemban, (2) SIPKD belum dapat memberikan dampak terhadap penyelesaian pekerjaan lebih cepat, (3) SIPKD belum bisa meningkatkan efektivitas dan produktivitas pekerjaan.

Fakta empiris menunjukkan bahwa pengelola keuangan di beberapa perangkat daerah masih mengalami kesulitan dalam mengoperasionalkan SIPKD karena belum tersedianya sarana dan prasarana yang mendukung. Oleh karena itu, perangkat daerah belum menerima impact SIPKD dalam peningkatkan efektivitas dan produktivitas untuk menyelesaikan pekerjaan. Hal tersebut disebabkan masih banyaknya kegiatan pengelolaan keuangan daerah yang diselesaikan secara manual atau tanpa menggunakan aplikasi SIPKD.

Hasil penelitian ini belum mampu memberikan dukungan terhadap teori Tecnology Acceptance Model (TAM) yang menyatakan bahwa individu menolak atau menerima suatu sistem teknologi informasi ditentukan oleh dua konstruk, yaitu manfaat yang dirasakan (perceived usefulness) dan kemudahan penggunaan yang dirasakan (perceived easy of use).Hasil penelitian ini juga tidak sesuai dengan penelitian Venkatesh dan Davis (2000), Venkatesh dkk. (2003), Al-Gahtani dkk. (2007), Lawan dan Dahalin (2011), Venkatesh dkk. (2012), Mahendra dan Affandy (2013), dan Widnyana dan Yadnyana (2015).

\section{Pengaruh faktor ekspektasi usaha (effort} expectancy) terhadap niat perilaku (behavioral intention)untuk menggunakan SIPKD.

Pengujian statistik menghasilkan nilai koefisien jalur ekspektasi usaha sebesar $-0,075$, nilai t statistik 1,358 , dan $p$ value 0,175 . Bukti empiris penelitian ini tidak mendukung hipotesis 2 . hal ini menunjukkan bahwa tingkat kemudahan dalam penggunaan SIPKD tidak berpengaruh 
terhadap niat responden untuk menggunakan SIPKD ( $\mathbf{H}_{2}$ Ditolak).

Kondisi tersebut disebabkan oleh sulit untuk menjadi terampil dalam menggunakan SIPKD. Hal tersebut dikarenakan SIPKD harus disesuaikan dengan perubahan Sistem Akuntansi Pemerintah dari cash toward acrual menjadi acrual basis serta perubahan yang terjadi terkait dengan organisasi dan tata laksana Pemerintah Kabupaten Semarang. Adanya kondisi tersebut penyesuaian terhadap aplikasi SIPKD harus diikuti oleh pengelola keuangan selaku pengguna anggaran dengan harapan akan dapat mempengaruhi tingkat kemudahan responden dalam menggunakan SIPKD. Faktor lainya yakni adanya penolakan terhadap perubahan. Penolakan terhadap perubahan ini disebabkan karena sistemnya bukan karena manusianya. Pengguna SIPKD keberatan karena sistem yang diterapkan belum sesuai dengan yang diharapkan.

Hasil penelitian ini tidak mendukung teori TAM yang menyatakan kemudahan persepsian (perceived easy of use) akan mempengaruhi kegunaan persepsian (perceived usefulness). Pemakai sistem akan menggunakan sistem jika merasa bahwa sistem tersebut mudah digunakan. Hal ini juga tidak sesuai dengan penelitian
Venkatesh dkk. (2003), Mahendra dan Affandy (2013), dan Putra dan Ariyanti (2013) yang menemukan bahwa niat dipengaruhi oleh ekspektasi usaha.

\section{Pengaruh faktor pengaruh sosial (social influence) terhadap niat perilaku (behavioral intention)untuk menggunakan SIPKD}

Hasil pengujian signifikansi menunjukkan pengaruh social influence terhadap niat perilaku tidak signifikan, yaitu nilai t statistik $1,339, p$ value 0,181 , dan nilai koefisien jalur sebesar 0,097. Hal ini menunjukkan bahwa pengaruh sosial tidak mempengaruhi niat responden untuk menggunakan SIPKD ( $\mathrm{H}_{3}$ Ditolak).

Tidak signifikannya pengaruh sosial terhadap niat menggunakan SIPKD disebabkan kurangnya dorongan dalam penggunaan SIPKD dari teman sekerja dan pimpinan perangkat daerah. Hal ini disebabkan masih rendahnya tingkat pemahaman dan penggunaan sistem teknologi informasi pada aparatur pemerintah daerah. Tidak semua aparatur pemerintah daerah memahami dan menggunakan sistem teknologi informasi yang bersifat komplek sehingga dapat menimbulkan persepsi yang berbeda terhadap teknologi informasi antar teman sekerja. Selain itu, kurangnya dukungan dan 
motivasi pimpinan untuk kelancaran menggunakan SIPKD. Kurangnya motivasi tersebut juga dapat dimaklumi karena prestasi kerja Aparatur Sipil Negara (ASN) bagi jabatan fungsional umum termasuk pengelola keuangan sulit diukur. Individu akan merasa prestasi kerja ASN tidak memberikan dampak yang jelas terhadap dirinya.

Hasil penelitian ini belum dapat memberikan dukungan teori UTAUT, secara empiris hasil penelitian ini tidak sesuai dengan hasil penelitian Sedana dan Wijaya (2010), Lawan dan Dahalin (2011), Mahendra dan Affandy (2013) dan Iriani dkk. (2014) yang membuktikan bahwa pengaruh sosial (social influence) berpengaruh positif terhadap niat menggunakan teknologi informasi.

\section{Pengaruh faktor kondisi yang memfasilitasi (facilitating conditions) terhadap niat perilaku (behavioral intention)untuk menggunakan SIPKD}

Hasil pengujian hipotesis
menunjukkan bahwa kondisi yang
memfasilitasi tidak berpengaruh terhadap
niat perilaku untuk menggunakan SIPKD
yaitu nilai koefisien jalur sebesar 0,066 , nilai
t statistik 0,693 , dan $p$ value $0,336\left(\mathbf{H}_{4}\right.$ a

\section{Ditolak).}

Penyebab facilitating conditions tidak berpengaruh terhadap niat perilaku yakni adanya kendala dalam implementasi SIPKD di Kabupaten Semarang seperti: belum memadainya sarana dan prasarana, luasnya wilayah Kabupaten Semarang dengan perangkat daerah yang tersebar mempersulit penyediaan internet sebagai sarana pendukung utama operasionalisasi online SIPKD. Penyebab lainnya yaitu aplikasi SIPKD belum kompatibel dengan teknologi lain yang mereka gunakan atau dapat dikatakan SIPKD belum terintegrasi dengan baik dengan aplikasi lain (misalnya: Sistem Pengelolaan Barang Daerah).

Hasil penelitian ini belum dapat mendukung UTAUT 2 oleh Lawan dan Dahalin (2011), Venkatesh dkk. (2012), dan Mahendra dan Affandy (2013) menyatakan kondisi yang memfasilitasi mempengaruhi niat pemanfaatan teknologi informasi.

Usia (age), jenis kelamin (gender), dan pengalaman (experience) memoderasi pengaruh kondisi yang memfasilitasi (facilitating conditions) terhadap niat perilaku (behavioral intention) untuk menggunakan SIPKD

Hasil pengujian hipotesis menunjukkan nilai koefisien jalur sebesar 0,019 , nilai t statistik 0,012 , dan $p$ value 0,832 yang berarti bahwa usia, jenis kelamin, dan pengalaman tidak memoderasi 
pengaruh kondisi yang memfasilitasi terhadap niat perilakuuntuk menggunakan SIPKD (H4b Ditolak).

Pengaruh moderasi yang tidak signifikan tersebut disebabkan penggunaan SIPKD bersifat mandatory. Pengelola keuangan wajib menggunakan sistem informasi sehingga pengguna dengan usia, jenis kelamin, dan pengalaman yang berbeda akan tetap berusaha dapat mengoperasionalkan SIPKD. Oleh karena itu, faktor usia, jenis kelamin, dan pengalaman bukan merupakan hal yang secara signifikan mempengaruhi niat penggunaan SIPKD. Hasil penelitian ini tidak konsisten dengan penelitian Venkatesh dkk. (2012) yang menyatakan bahwa faktor usia, jenis kelamin dan pengalaman mampu memoderasi facilitating conditions dan behavioral intention.

\section{Pengaruh faktor kondisi yang memfasilitasi (facilitating conditions) terhadap perilaku menggunakan (use behavior) SIPKD}

Hasil pengujian hipotesis menunjukkan nilai koefisien jalur sebesar 0,173, nilai t statistik 2,779, dan $p$ value 0,005 yang berarti facilitating conditions berpengaruh positif dan signifikan terhadap perilaku menggunakan SIPKD Diterima). Hasil ini dapat diartikan bahwa semakin baik kondisi-kondisi yang memfasilitasi yang disediakan organisasi maka semakin berpengaruh terhadap perilaku menggunakan sistem teknologi informasi.

Hasil penelitian ini mendukung penelitian yang dilakukan oleh Venkatesh dkk. (2003), Lawan dan Dahalin (2011), Venkatesh dkk. (2012), dan Widnyana dan Yadnyana (2015) yang menemukan bahwa kondisi memfasilitasi memiliki dampak signifikan pada use behavior.

\section{Pengaruh faktor motivasi hedonis (hedonic motivation)terhadap niat perilaku (behavioral intention) untuk menggunakan SIPKD}

Hasil pengujian hipotesis menunjukkan nilai koefisien jalur sebesar 0,158 , nilai $\mathrm{t}$ statistik 2,186 , dan $p$ value 0,029 yang berarti bahwa motivasi hedonis berpengaruh positif dan signifikan terhadap niat perilaku (H6a Diterima). Hasil ini menunjukkan kesenangan yang diperoleh responden dalam menggunakan SIPKD berpengaruh terhadap niat penggunaan SIPKD. Semakin besar kesenangan yang diperoleh dari penggunaan teknologi maka semakin berpengaruh pada niat penggunaan sistem teknologi informasi.

Hasil penelitian ini mendukung penelitian Venkatesh dkk. (2012) yang 
menyatakan motivasi hedonis sebagai kesenangan yang berasal dari penggunaan teknologi, dan telah terbukti memiliki peran penting dalam menentukan penerimaan teknologi. Demikian juga Brown dan Venkatesh (2005), Putra dan Ariyanti (2013), Raman dan Don (2013) yang juga menyatakan motivasi hedonis berpengaruh positif dan signifikan terhadap niat pada penerimaan teknologi informasi.

Usia (age), jenis kelamin (gender), dan pengalaman (experience) memoderasi pengaruh motivasi hedonis (hedonic motivation) terhadap niat perilaku (behavioral intention) untuk menggunakan SIPKD

Hasil pengujian hipotesis menunjukkan nilai koefisien jalur sebesar 0,078 , nilai $\mathrm{t}$ statistik 0,992 dan $p$ value 0,321 yang berarti age, gender, dan experience tidak dapat memoderasi pengaruh motivasi hedonis terhadap niat perilaku menggunakan SIPKD $\left(\mathrm{H}_{6} \mathrm{~b}\right.$ Ditolak). Hasil ini dapat disimpulkan bahwa tidak ada perbedaan kesenangan baik lakilaki maupun perempuan pada usia tertentu dan dengan pengalaman tertentu yang mendorong individu untuk menggunakan SIPKD.

Hal ini disebabkan karena ASN pengguna SIPKD memiliki niat menggunakan SIPKD lebih karena keinginan untuk dapat melaksanakan tugas pokok dan fungsinya dengan baik, yaitu menyelesaikan tugas-tugas perencanaan, penatausahaan, dan atau pelaporan keuangan. oleh karena itu perbedaan usia, jenis kelamin, maupun pengalaman tidak mempengaruhi niat atau tidak menggunakan SIPKD.

Hasil penelitian ini tidak mendukung hasil penelitian Venkatesh dkk. (2012) yang menyatakan karakteristik individu, yaitu jenis kelamin, usia, dan pengalaman, bersama-sama memoderasi pengaruh motivasi hedonis terhadap niat perilaku, dimana pengaruh motivasi hedonis pada niat perilaku lebih kuat untuk pria yang lebih muda dengan pengalaman kurang dengan teknologi.

Pengaruh faktor kebiasaan (habit) terhadap niat perilaku (behavioral intention) untuk menggunakan SIPKD

Hasil pengujian hipotesis menunjukkan nilai koefisien jalur sebesar 0,473 , nilai t statistik 7,169 , dan $p$ value 0,000 yang berarti kebiasaan berpengaruh positif signifikan terhadap niat perilaku (H7a Diterima). Hal ini menunjukkan bahwa kebiasaan responden menggunakan SIPKD, keharusan menggunakan SIPKD, dan ketergantungan pada penggunaan SIPKD dalam menyelesaikan pekerjaan 
mempengaruhi secara signifikan terhadap niat responden untuk menggunakan SIPKD. Semakin sering ASN menggunakan SIPKD maka akan semakin kuat niat untuk menggunakan SIPKD.

Hasil penelitian ini mendukung penelitian Kim dan Malhotra (2005) yang membuktikan bahwa penggunaan sebelumnya merupakan prediktor yang kuat dalam penggunaan teknologi di masa mendatang. Pahnila dkk. (2011), Harsono dan Suryana (2014), dan Prabowo (2015)juga menemukan bahwa kebiasaan mempunyai pengaruh yang signifikan terhadap niat keperilakuan pada pengguna teknologi.

Usia (age), jenis kelamin (gender), dan pengalaman (experience) memoderasi pengaruh kebiasaan (habit) terhadap niat perilaku (behavioral intention) untuk menggunakan SIPKD

Hasil penelitian menunjukkan nilai koefisien jalur sebesar $-0,167$, nilai t statistik 1,632 , dan $p$ value 0,105 yang berarti bahwa interaksi variabel moderator age, gender, dan experience dengan variabel kebiasaan tidak mempengaruhi niat individu untuk menggunakan SIPKD (H7b Ditolak). Hal ini menunjukkan bahwa usia, jenis kelamin, dan pengalaman tidak dapat memoderasi variabel kebiasaan dan niat perilaku. Dengan kata lain tidak ada perbedaan kebiasaan antara pengguna dengan jenis kelamin lakilaki dengan perempuan, tingkat usia muda dengan tua, serta tingkat pengalaman tertentu yang mendorong dalam penggunaan SIPKD.

Tidak signifikannya pengaruh variabel moderator tersebut karena responden memiliki niat menggunakan dan menyesuaikan diri dengan sistem teknologi informasi yang bersifat mandatory. Responden menggunakan SIPKD dalam rangka mendukung tugas pokok dan fungsi pengelolaan keuangan daerah. Sifat mandatory tersebut yang menyebabkan perbedaan usia, jenis kelamin, maupun pengalaman tidak mempengaruhi niat perilaku pengguna untuk menggunakan SIPKD. Hasil penelitian ini bertentangan dengan penelitian Venkatesh dkk. (2012) yang menyatakan bahwa efek usia, jenis kelamin, dan pengalaman dapat memoderasi pengaruh habit terhadap behavioral intention, sehingga pengaruhnya akan menjadi lebih kuat terhadap pria yang lebih tua dengan tingkat pengalaman yang tinggi dengan teknologi.

\section{Pengaruh faktor kebiasaan (habit) terhadap perilaku menggunakan (use behavior) SIPKD}

$$
\text { Hasil pengujian hipotesis }
$$

menunjukkan nilai koefisien jalur sebesar 
0,158 , nilai $\mathrm{t}$ statistik 2,186 , dan $p$ value 0,029 yang berarti kebiasaan berpengaruh signifikan terhadap perilaku penggunaan (Hsa Diterima). Hasil ini menunjukkan bahwa kebiasaan, keharusan dan ketergantungan responden dalam penggunaan SIPKD untuk menyelesaikan pekerjaan berpengaruh positif dan signifikan terhadap perilaku menggunakan SIPKD. Semakin sering ASN menggunakan SIPKD maka akan semakin sering pula perilaku (use behavior) menggunakan SIPKD.

Hasil penelitian ini mendukung teori UTAUT 2 oleh Venkatesh dkk. (2012) yang menyatakan bahwa konstruk kebiasaan (habit) merupakan prediktor yang kuat dari perilaku menggunakan (use behavior) sistem informasi. Hasil yang sama juga diungkapkan oleh Harsono dan Suryana (2014) yang menemukan bahwa kebiasaan berpengaruh positif terhadap perilaku menggunakan aplikasi line.

Usia (age), jenis kelamin (gender), dan pengalaman (experience) memoderasi pengaruh kebiasaan (habit) terhadap perilaku menggunakan (use behavior) SIPKD

Hasil penelitian tidak menemukan adanya interaksi variabel moderator age, gender, dan experience antara habit dan perilaku menggunakan SIPKD $\left(\mathbf{H}_{8} \mathbf{b}\right.$
Ditolak). Hal ini menunjukkan bahwa perbedaan usia, jenis kelamin, dan pengalaman tidka dapat memoderasi hubungan antara variabel kebiasaan (habit) dan perilaku menggunakan (use Behavior) SIPKD. Dengan kata lain tidak ada perbedaan kebiasaan (habit) baik laki-laki maupun perempuan pada usia tertentu, dan pengalaman tertentu yang mendorong individu dalam penggunaan SIPKD.

Penyebab tidak signifikan tersebut yakni ASN dalam melaksanakan tugas sebagai pengelola keuangan dan pengguna SIPKD berdasarkan penugasan yang diinstruksikan oleh pimpinan perangkat daerah. Sebagian besar penugasan pengelola keuangan dilakukan berdasarkan keterbatasan sumber daya aparatur dan kesediaan aparatur yang ditunjuk. Oleh karena itu, faktor-faktor lain seperti pendidikan, pengalaman, usia dan jenis kelamin bukan merupakan faktor yang mempengaruhi penugasan sebagai pengelola keuangan. Dengan demikian perbedaan usia, jenis kelamin, maupun pengalaman tidak mempengaruhi perilaku menggunakan SIPKD.

Hasil penelitian ini tidak sesuai dengan penelitian Venkatesh dkk. (2012) yang menyatakan bahwa efek usia, jenis kelamin, dan pengalaman dapat memoderasi 
pengaruh kebiasaan (habit) terhadap perilaku (use behavior) sehingga pengaruhnya akan menjadi lebih kuat di antara pria yang lebih tua dengan tingkat pengalaman yang signifikan dengan teknologi.

Pengaruh niat perilaku (behavioral intention) terhadap perilaku menggunakan (use behavior) SIPKD

Hasil pengujian hipotesis menunjukkan nilai koefisien jalur sebesar 0,316 , nilai $\mathrm{t}$ statistik 4,142 , dan $p$ value 0,000 yang berarti behavioral intention berpengaruh signifikan terhadap use behavior (Hoa Diterima). Hasil ini menunjukkan bahwa niat menggunakan berpengaruh signifikan terhadap perilaku responden untuk menggunakan SIPKD. Semakin tinggi niat ASN untuk menggunakan SIPKD maka akan semakin tinggi tingkat intensitas penggunaan SIPKD yang dilakukan oleh responden.

Hasil penelitian ini mendukung teori UTAUT yang diungkapkan oleh Venkatesh dkk. (2003) dan UTAUT 2 oleh Venkatesh dkk. (2012) bahwa niat perilaku (behavioral intention) berpengaruh signifikan terhadap perilaku pemakaian (use behavior). Temuan penelitian ini juga sesuai dengan Theory of Reasoned Action (TRA) oleh Fishbein dan Ajzen (1975) yang menyebutkan bahwa tindakan dilakukan karena individu mempunyai minat atau keinginan untuk melakukannya.

Pengalaman (experience) memoderasi pengaruh niat perilaku (behavioral intention) terhadap perilaku menggunakan (use behavior) SIPKD

Hasil penelitian menunjukkan nilai koefisien jalur sebesar -0,063, nilai t statistik 0,902 , dan $p$ value 0,367 yang berarti interaksi variabel moderator experience dengan niat perilaku (behavioral intention) tidak berpengaruh signifikan terhadap perilaku menggunakan (use behavior) SIPKD (H9b Ditolak). Hasil ini menunjukkan bahwa pengalaman (experience) tidak dapat memoderasi hubungan antara niat perilaku (behavioral intention) dan perilaku menggunakan (use behavior) SIPKD. Dengan kata lain tidak ada perbedaan pengalaman dalam menggunakan SIPKD di tempat kerja responden saat ini yang mendorong responden dalam penggunaan SIPKD.

Pengaruh variabel moderator yang tidak signifikan dikarenakan SIPKD adalah satu-satunya alat bantu yang outputnya merupakan hasil akhir proses perencanaan, penganggaran, penatausahaan dan pelaporan. Oleh karena itu, pengelola keuangan akan berusaha untuk memahami dan

60 Faktor-Faktor Yang Memengaruhi Penerimaan Dan Penggunaan Sistem Informasi Pengelolaan Keuangan Daerah (Sipkd) Dalam Perspektif The Unified Theory Of Acceptance And Use Of Technology 2 (Utaut 2) Di Kabupaten Semarang 
menggunakan SIPKD dalam rangka mendukung tugas pokok dan fungsi pengelolaan keuangan daerah.

Hasil penelitian ini tidak mendukung penelitian Jasperson dkk. (2005) dan Kim dan Malhotra (2005) yang menyatakan bahwa jika pengalaman meningkat maka secara otomatis akan mempengaruhi perilaku pengguna dan pada akhirnya akan berdampak pada niat perilaku penggunaan teknologi. Berbeda halnya dengan penelitian Venkatesh dkk. (2003) yang menyatakan behavioral intention hanya berpengaruh secara langsung terhadap use behavior tanpa disertai efek moderasi.

\section{KESIMPULAN DAN SARAN}

\section{Kesimpulan}

Berdasarkan hasil pengujian hipotesis ditemukan 5 hipotesis $\left(\mathrm{H}_{5}, \mathrm{H}_{6} \mathrm{a}\right.$, $\mathrm{H}_{7} \mathrm{a}, \mathrm{H}_{8} \mathrm{a}$, dan $\left.\mathrm{H}_{9} \mathrm{a}\right)$ diterima, sedangkan 9 hipotesis lainnya $\left(\mathrm{H}_{1}, \mathrm{H}_{2}, \mathrm{H}_{3}, \mathrm{H}_{4} \mathrm{a}, \mathrm{H}_{4} \mathrm{~b}, \mathrm{H}_{6} \mathrm{~b}\right.$, $\mathrm{H}_{7} \mathrm{~b}, \mathrm{H}_{8} \mathrm{~b}$ dan $\left.\mathrm{H}_{9} \mathrm{~b}\right)$ ditolak. Niat untuk menggunakan sistem teknologi informasi dipengaruhi oleh beberapa aspek. Hasil penelitian ini menunjukkan bahwa semakin tinggi motivasi hedonis atau kesenangan menggunakan teknologi maka semakin tinggi niat untuk menggunakan sistem teknologi informasi. SIPKD menimbulkan rasa senang dan nyaman karena pengguna merasa mudah menggunakan dan dapat menyelesaikan pekerjaan dengan kesalahan yang minimal, dengan demikian pekerjaan yang dilakukan menjadi lebih menarik jika memanfaatkan teknologi informasi.

Kebiasaan (habit) responden dalam menggunakan SIPKD juga akan meningkatkan niat (behavioral intention) dan perilaku (use behavior) untuk menggunakan SIPKD. Hasil akhir proses pengelolaan keuangan daerah yang terdiri dari perencanaan, penatausahaan, dan pelaporan keuangan daerah, diperoleh dari output SIPKD, sehingga pengelola keuangan daerah akan sering menggunakan sistem.

Perilaku menggunakan (use behavior) merupakan tindakan nyata yang dilakukan oleh individu, yaitu perilaku menggunakan sistem akan semakin meningkat jika kondisi yang memfasilitasi (facilitating conditions) semakin baik atau ideal, dengan demikian penyediaan fasilitas infrastruktur organisasi dan teknis yang memadai akan memberikan dampak meningkatnya penggunaan SIPKD. Kondisi memfasilitasi yang ideal dalam mendukung penggunaan sistem berupa bantuan dari fasilitator atau tenaga khusus jika terjadi masalah dalam penggunaan SIPKD, serta pelaksanaan pelatihan atau bimbingan teknis akan meningkatkan perilaku menggunakan 
SIPKD. Selain kondisi yang memfasilitasi, niat keperilakuan (behavioral intention) yang kuat juga akan meningkatkan perilaku menggunakan sistem. Niat yang kuat penggunaan SIPKD didorong oleh kebiasaan dan kesenangan individu dalam menggunakan SIPKD.

Penggunaan sistem di organisasi dapat bersifat sukarela (voluntary) atau wajib (mandatory). SIPKD merupakan pemakaian wajib yang sifatnya diharuskan, dengan demikian semua pemakai harus menggunakan sistem, namun demikian bukan berarti tidak ada variasi pemakaian sistem sehingga tidak dapat diprediksi. Hal ini sebagaimana diungkapkan oleh Harwick dan Barki (1994) dalam Hartono (2008) yang beropini bahwa perilaku pemakaian wajib juga bervariasi. Pemakaian wajib merupakan perilaku di bawah kendali seseorang yang berbasis pada pertimbangan normatif atau keharusan. Pemakai wajib dapat memilih untuk menggunakan sistem atau tidak dalam bentuk membantah atasannya, atau tidak sepenuhnya menggunakan sistem jika merasa sistem tidak bermanfaat atau jika tidak ada pengawasan. Dapat disimpulkan bahwa pemakaian wajib dapat menyebabkan tingkat pemakaian sistem yang bervariasi antar pemakai sistem.

\section{Implikasi}

Penelitian ini memberikan kontribusi bagi literatur akuntansi keperilakuan tentang kesuksesan sistem informasi dengan menggunakan model UTAUT 2. Dalam penelitian ini diperoleh bukti empiris bahwa persepsi kemanfaatan, kemudahan penggunaan, pengaruh sosial, dan kondisi yang memfasilitasi tidak berpengaruh terhadap niat dalam menggunakan system. Selain itu usia, jenis kelamin, dan pengalaman yang tidak memoderasi hubungan variabel-variabel eksogen dengan niat dan perilaku. Hal ini tidak sejalan dengan pendekatan teori UTAUT 2 yang menekankan persepsi-persepsi tersebut memiliki hubungan untuk memprediksi niat dan perilaku dalam menggunakan sistem informasi. Namun demikian hasil penelitian ini memberikan referensi bahwa behavioral intention dipengaruhi secara signifikan oleh hedonic motivation dan habit, use behavior dipengaruhi oleh facilitating condition, habit, dan behavioral intention tanpa moderasi dilingkungan pengaturan wajib. Pendekatan dengan teori UTAUT 2 tidak membedakan lingkungan pengaturan (sukarela atau wajib) dan organisasi.

Hasil penelitian ini dapat digunakan sebagai usulan untuk pengembangan sistem maupun pengambil keputusan. Bagi 
teknisi/pengembang sistem, hasil penelitian dapat dijadikan masukan untuk pengembangan sistem dan tolok ukur dalam evaluasi sistem. Hasil penelitian dapat dijadikan bahan evaluasi dalam penerapan SIPKD sehingga menjadi sistem yang berkelanjutan. Selain itu hasil penelitian juga dapat digunakan sebagai bahan pertimbangan dalam merencanakan pengembangan sumber daya yang berkompeten dalam menunjang operasional sistem, sehingga dapat memberikan dampak positif baik bagi pengguna SIPKD maupun organisasi.

\section{Keterbatasan dan Saran}

Dibandingkan dengan penelitianpenelitian penerimaan sistem teknologi informasi sebelumnya, nilai Adjusted $R^{2}$ yang diperoleh relatif rendah sehingga dapat diindikasikan bahwa banyak faktor-faktor penting yang belum dimasukkan untuk penerimaan SIPKD. Selain itu, Penelitian ini juga belum bisa membuktikan peran variabel usia (age), jenis kelamin (gender), dan pengalaman (experience) sebagai pemoderasi variabel kondisi-kondisi yang memfasilitasi (facilitating conditions), motivasi hedonis (hedonic motivations), dan kebiasaan (habit) terhadap niat perilaku (behavioral intention) dan perilaku menggunakan (use behavior) sistem teknologi informasi.

Keterbatasan penelitian tersebut dapat menjadi masukan untuk penelitian yang akan datang agar dapat diperoleh model dengan kriteria kuat dengan menambahkan dan memperluas variabel yang akan diteliti. Penambahan variabel prediktor yang mempengaruhi niat perilaku (behavioral intention) dapat meningkatkan nilai Adjusted $R^{2}$.

Ekspektasi kinerja tidak signifikan mempengaruhi niat menggunakan sistem, hal ini dimungkinkan kurangnya faktorfaktor institusional berupa dukungan dan komitmen manajemen puncak (top management commitmen) dalam hal ini kepala perangkat daerah maupun manajemen lokal (local management commitmen) yaitu atasan langsung yang akan mempengaruhi kepercayaan-kepercayaan kegunaan (usefulness). Jika manajemen puncak memberikan isyarat pentingnya teknologi kepada perangkat daerah berupa dana dan sumber daya untuk melakukan kegiatankegiatan teknologi, atasan langsung akan mempengaruhi perilaku individual pengguna. Dalam berbagai literatur sistem informasi, bahwa kepercayaan-kepercayaan (beliefe) memicu perilaku (behavior) penggunaan teknologi informasi dan 
mempunyai dampak ke niat dan penggunaan. Untuk itu pada penelitian mendatang diusulkan untuk mengikutsertakan faktor-faktor institusional sebagai variabel moderasi pengaruh ekspektasi kinerja terhadap niat.

Pengaruh sosial (social influence) merupakan faktor-faktor yang tidak signifikan, kemungkinan faktor-faktor sosial berpengaruh ke niat melalui variabel lain yang tidak diteliti di penelitian ini, misalnya lewat variabel image. Venkatesh dan Davis (2000) menemukan hubungan yang signifikan antara norma-norma subyektif (subjective norm) dengan kepercayaankepercayaan image.dengan demikian penelitian berikutnya dapat menyertakan variabel image pada penelitian sebagai variabel mediasi.

Kondisi yang memfasilitasi (facilitating conditions) tidak signifikan mempengaruhi niat penggunaan SIPKD, hal ini dimungkinkan infrastruktur organisasi dan teknis yang diterima responden memiliki kuantitas maupun kualitas yang berbeda, sedangkan dalam penggunaan teknologi yang sifatnya mandatory frekuensi perilaku menggunakan hampir sama. Penelitian mendatang perlu diperhatikan ketersediaan kondisi-kondisi yang memfasilitasi yang setara antara perangkat daerah yang dijadikan sampel.

Penelitian ini hanya meneliti pengaruh konstruk-konstruk ke niat keperilakuan (behavioral intention) dan ke perilaku menggunakan (use behavior), tetapi belum menghubungkan ke hasil-hasil pemakaian. Kadang diasumsikan bahwa pemakaian akan menghasilkan hasil-hasil yang positif. Asumsi ini perlu diteliti lebih lanjut.

\section{DAFTAR PUSTAKA}

Ajzen, I. 1991. "The Theory of Planned Behavior". Organizational Behavior And Human Decision Processes, Vol. 50, No. 2, 179-211.

Ajzen, I., \& Madden, T. J., 1986, Prediction of Goal-Directed Behavior: Attitudes, Intentions, and Perceived Behavioral Control, Journal of Experimental Social Psychology, Vol. 22, 453-474.

Al-Gahtani, S. S., G. S. Hubona, dan Wang J., 2007, Information Technology (IT) in Saudi Arabia: Culture and the Acceptance and Use of IT". Information And Management, Vol. 44, No. 8, 681-691.

Alba, J. W., dan Hutchinson J.W., 1987, "Dimensions of Consumer 
Expertise". The Journal of Consumer

Research, Vol. 13, No. 4, 411-454.

Brown, S. A., dan Venkatesh V., 2005. "Model Of Adoption Of Technology In Households: A Baseline Model Test And Extension Incorporating Household Life Cycle, MIS Quarterly, Vol. 29, No. 3, 399-426.

Chau, P. Y. K., dan Hui, K.L., 1998, Identifying Early Adopters of New IT Products: A case of Windows 95, Information \& Management, Vol. 33, No. 5, 225-230.

Davis, F. D., Bagozzi, R. P., dan Warshaw P. R., 1989, User Acceptance Of Computer Technology: A Comparison Of Two Theoritical Model, Management Science, Vol. 35, No. 8, 982-1003.

Direktorat Jenderal Keuangan Daerah Kementerian Dalam Negeri. 2016. "Sistem Informasi Pengelolaan Keuangan Daerah (SIPKD)" http://keuda.kemendagri.go.id/sipkd. [diakses pada 25 Desember 2016].

Fishbein, M., dan I. Ajzen I., 1975, Belief, Attitude, Intention And Behavior: An Introduction to Theory and Research. Reading, Massachusetts: AddisonWesley.
Ghozali, I. 2013. Aplikasi Analisis Multivariate dengan Program IBM SPSS 21. Semarang: Badan Penerbit Universitas Diponegoro.

Ghozali, I., dan H. Latan H., 2016. Partial Least Square Konsep: Metode dan Aplikasi: Menggunakan Program WarpPLS 5.0. 3 ed. Semarang: Badan Penerbit - Universitas Diponegoro.

Hall, D. T., dan Mansfield R., 1975. "Relationships of Age and Seniority with Career Variables of Engineers and Scientists". Journal of Applied Psychology, Vol. 60, No. 2, 201210.

Harsono, L. D., dan Suryana L. A., 2014 , Factors Affecting the Use Behavior of Social Media Using UTAUT 2 Model, Artikel dipresentasikan pada Proceedings of the First Asia-Pacific Conference on Global Business, Economics, Finance and Social Sciences (AP14Singapore Conference), di Singapore.

Hartono, J. 2008. Sistem Informasi Keperilakuan (Edisi Revisi). Yogyakarta: ANDI.

Heijden, H. V. D. 2004. "User Acceptance of Hedonic Information Systems". 
MIS Quarterly, Vol. 28, No. 4, 695-704.

Iriani, S., Suyanto M., dan Amborowati A., 2014. "Pengujian Sistem Informasi Pengelolaan Keuangan Daerah Berbasis Web Kabupaten Pacitan Dengan Menggunakan Unified Theory Of Acceptance And Use Of Technology (UTAUT)". Indonesian Journal on Networking and Security, Vol. 3, No. 2, 60-66.

Jasperson, J. S., Carter P. E., dan Mud R. W. Z., 2005, A Comprehensive Conceptualization of Post-Adoptive Behaviors Associated with Information Technology Enabled Work Systems, MIS Quarterly, Vol. 29, No. 3, 525-557.

Jennings, J. M., dan Jacoby L. L., 1993. "Automatic Versus Intentional Uses of Memory: Aging, Attention, and Control". Psychology and Aging, Vol. 8, No. 2, 283-293.

Kim, S. S., dan Malhotra N. K., 2005, A Longitudinal Model of Continued IS Use: An Integrative View of Four Mechanisms Underlying Postadoption Phenomena, Management Science, Vol. 51, No. $5,741-755$.
Kim, S. S., Malhotra N. K., dan Narasimhan S., 2005, Research Note - Two Competing Perspectives on Automatic Use: A Theoretical and Empirical Comparison, Information Systems Research, Vol. 16, No. 4, 418-432.

Lawan, A., dan Dahalin Z. M., 2011. Effectiveness of Telecentre using a Model of Unified Theory of Acceptance and Use of Technology (UTAUT): Structural Equation Modeling Approach, CIS Journal, Vol. 2, No. 9, 402-412.

Limayem, M., Hirt S. G., dan Cheung C. M. K., 2007, How Habit Limits The Predictive Power of Intention: The Case of Information Systems Continuance, MIS Quarterly, Vol. 31, No. 4, 705-737.

Mahendra, A. R., dan Affandy D. P., 2013, Faktor-Faktor yang Mempengaruhi Minat Pemanfaatan Sistem Informasi Pengelola Keuangan Daerah (SIPKD) (Studi Kasus pada Pemerintah Kota Blitar), Jurnal Ilmiah Mahasiswa FEB, Vol. 1, No. $2,1-23$.

Morris, M. G., Venkatesh V., dan Ackerman P. L., 2005, Gender and Age Differences in Employee 
Decisions About New Technology: An Extension to the Theory of Planned Behavior, IEEE Transactions On Engineering Management, Vol. 52, No. 1, 69-84. Pahnila, S., Siponen M., dan Zheng X., 2011. Integrating Habit into UTAUT: The Chinese eBay Case". Pacific Asia Journal of the Association for Information Systems, Vol. 3, No. 2, 1-30.

Prabowo, A. S., 2015. Evaluasi Penerimaan User Teknologi Mobile Banking di Yogyakarta, Fakultas Teknik, Universitas Gadjah Mada, Yogyakarta.

Putra, G., dan Ariyanti M., 2013, Pengaruh Faktor-Faktor Dalam Modified Unified Theory Of Acceptance And Use Of Technology 2 (UTAUT 2) Terhadap Niat Prospective Users Untuk Mengadopsi Home Digital Services PT. Telkom di Surabaya, Jurnal Manajemen Indonesia, Vol. 12, No. 4, 59-76.

Raman, A., dan Don Y., 2013, Preservice Teachers' Acceptance of Learning Management Software: An Application of the UTAUT2 Model". International Education Studies, Vol. 6, No. 7, 157-164.

Sedana, I. G. N., dan Wijaya S. W., 2010, UTAUT Model for Understanding Learning Management System, Internet Working Indonesia Journal, Vol. 2, No. 2, 27-32.

Taylor, S., dan Todd P. A., 1995, Understanding Information Technology Usage: A Test of Competing Models, Information Systems Research, Vol. 6, No. 2, 144-176.

Thong, J. Y. L., Hong S. J., dan Tam K. Y., 2006, The Effects of Post-Adoption Beliefs on the ExpectationConfirmation Model for Information Technology Continuance, International Journal of HumanComputer Studies, Vol. 64, No. 9, 799-810.

Venkatesh, V., dan Davis F. D., 2000, A Theoretical Extension of the Technology Acceptance Model: Four Longitudinal Field Studies, Management Science, Vol. 46, No. 2, 186-204.

Venkatesh, V., dan Morris M. G., 2000, Why Don't Men Ever Stop to Ask for Directions? Gender, Social Influence, and Their Role in Technology Acceptance and Usage Behavior, 
MIS Quarterly, Vol. 24, No. 1, 115-139.

Venkatesh, V., Morris M. G., Davis G. B, dan Davis F. D., 2003, User Acceptance of Information Technology: Toward a Unified View,. MIS Quarterly, Vol. 27, No. 3, 427-478.

Venkatesh, V., Thong J. Y. L., dan Xu X., 2012, Consumer Acceptance And Use Of Information Technology: Extending The Unified Theory Of Acceptance And Use Of Technology, MIS Quarterly, Vol. 36, No. 1, 157-178.

Wang, H. I., dan Yang H. L., 2005, The Role of Personality Traits in UTAUT Model under Online Stocking, Contemporary Management Research, Vol. 1, No. 1, 69-82.

Widnyana, I. I. D. G. P., dan Yadnyana I. K., 2015, Implikasi Model UTAUT Dalam Menjelaskan Faktor Niat Dan Penggunaan SIPKD Kabupaten Tabanan, E-Jurnal Akuntansi Universitas Udayana, Vol. 11, No. 2, 515-530. 